\title{
The Effect of Tribomechanical Micronization and Activation on Rheological, Thermophysical, and Some Physical Properties of Tapioca Starch
}

\author{
Zoran Herceg, ${ }^{1}$ Verica Batur, ${ }^{2}$ Anet Režek Jambrak, ${ }^{1}$ Tomislava Vukušić, \\ Ines Gmajnički, ${ }^{3}$ and Igor Špoljarić ${ }^{3}$ \\ ${ }^{1}$ Faculty of Food Technology and Biotechnology, University of Zagreb, Pierottijeva 6, Zagreb, Croatia \\ ${ }^{2}$ High School of Food Technology, Gjure Prejca 2, Zagreb, Croatia \\ ${ }^{3}$ Forensic Science Centre "Ivan Vučetić", Ilica 110, Zagreb, Croatia \\ Correspondence should be addressed to Zoran Herceg; zherceg@pbf.hr
}

Received 30 November 2012; Revised 4 February 2013; Accepted 5 February 2013

Academic Editor: R. J. Linhardt

Copyright (C) 2013 Zoran Herceg et al. This is an open access article distributed under the Creative Commons Attribution License, which permits unrestricted use, distribution, and reproduction in any medium, provided the original work is properly cited.

The aim of this research was to investigate the effect of tribomechanical treatments on rheological, thermophysical, and some physical properties of tapioca starch. Samples of tapioca starch were treated using laboratory equipment for tribomechanical micronization and activation (TMA equipment). Before and after the TMA treatment, analysis of the particle size and particle size distribution was carried out, in addition to scanning electron micrography in tapioca starch. Scanning electron micrography showed that tribomechanical processing of tapioca starch resulted in breaking accumulations of starch granules in the form of granules. Pasting parameters have shown that maximal viscosities of model starch suspension have been decreasing after tribomechanical treatment. On the basis of gelatinization curves, it can be concluded that there are changes in the gelatinization point after treatment, and there is decrease in enthalpy of gelatinization for model suspension. After tribomechanical treatment, changes in physical properties of starch suspensions were determined, as well as specific swelling capacity, solubility index, and turbidity of tapioca starch suspensions.

\section{Introduction}

Starch is present in food, whether it comes as a raw material or added as ingredient in order to achieve or improve certain properties. It has significant applications in the food industry, and is used as a tool for: thickening, stabilization of colloidal systems, moisture retention, flavor binding, gelling, film formation, improvement of product quality and other. Starch isolation from natural sources (seeds, tubers and fruit crops) gets a native starch which retains the original structure and properties. Due to its capability of improving water retention, it is used to improve textural properties, and due to low energy value-in the production of low-caloric foodstuffs [1$3]$.

Starch is a useful polymer and a cheap, natural material, the reason being the ease with which its physicochemical properties can be altered through chemical or enzyme modification and/or physical treatment $[1,4,5]$. There is great interest in novel methods to modify the structure of starch in the crystalline regions [6]. One of novel methods to modify the structure of starch is the process of tribomechanical micronization and activation (TMA process).

The process of tribomechanical micronization and activation (TMA), as well as the appropriate equipment, was patented in the year 1998 at the International Bureau of the WPO PCT Receiving Office in Geneva Switzerland, under number PCT/1B 99/00757 [7]. The TMA equipment is made up of housing and two rotor discs placed against each other. Each disc is furnished with 3-7 concentric circles-rings of teeth projecting from the surface of the disc-with specially constructed hard metal elements. The discs rotate in opposite directions at the same angular rate. The starting material enters the equipment through the central part of the rotor system by ventilator air streaming. Therefore, the particles are 
accelerated and, because of repeated changes in the direction of motion, collide, causing friction over short time intervals (less than $0.001 \mathrm{~s}$ ).

Application of tribomechanical micronization in food processing presents a novel nonthermal method, with low energy consumption and short treatment time as compared to traditional technological processes, and presents novel method for food processing that can be used for new product development as improvement of technological process which is the purpose of this paper. The investigation with tribomechanical activation (TMA) has been primarily focused on inorganic materials [8], but recently, investigations were directed to organic materials such as powdered whey proteins [8-10]. Previous investigations have shown that TMA treatment, besides breaking up developed agglomerates, may significantly change structural characteristics of starches and its reactivity [11]. Because of such effects on the physical and structural properties of proteins and corn starch, it is to be expected that the procedure of TMA treatment can cause similar changes on tapioca starch.

Application of tapioca starch is used in numerous industrial and food applications, including thickening and gelling. In many applications, the properties of native starch are not optimal, and therefore starch is used with different additives and ingredients or is modified in order to change and improve its functions [12-15]. The use of native tapioca starches may be highly inconvenient due to retrogradation and syneresis phenomena as well as low mechanical and thermal stability observed in such material. Starch is modified in a different manner in order to change its physicochemical properties as well as to obtain desired functional properties. Tapioca starch has no taste or smell; so, adding color, flavor, eggs, milk, cream and sweeteners can be recast in age at variety of products especially sweets.

The purpose of this research was to establish a possible significant influence of TMA treatment on rheological, thermophysical, and some physical properties of tapioca starch. The examinations of the influence of TMA treatment on the morphological characteristic of the tapioca starch were also performed.

\section{Materials and Methods}

2.1. Sample Preparation. Powdered tapioca starch sample (commercial name: Cream Gel 70001) has been used. Its composition has been declared by manufacturer (Cargill Benelux BV, SAS van Gent, The Netherland) as follows: water $13.11 \%$, starch $86.89 \%$, and $\mathrm{pH}-5.5$. Suspensions have been prepared by stirring the appropriated amount of tapioca starch powder and distilled water as stated in Table 1.

2.2. Tribomechanical Micronization. Powder tapioca starch was laboratory treated in the equipment for TMA (Figure 1). The laboratory TMA device is capable of treating samples within a wide range of rotor speeds (from 10,000 rpm up to of 22,000 rpm). The TMA optimized treatment was carried out at rotor speed $(20,000 \mathrm{rpm})$ and at ambient temperature. Tapioca starch was treated using the TMA equipment under
TABLE 1: Composition of tapioca starch suspensions: 1A — untreated; 1B-TMA treated.

\begin{tabular}{|c|c|c|c|}
\hline Sample & Preparation & Tapioca starch (g) & Water $(\mathrm{g})$ \\
\hline \multirow{2}{*}{$10 \%(\mathrm{w} / \mathrm{w})$ suspensions } & $1 \mathrm{~A}$ & 11.37 & 98.62 \\
\hline & $1 \mathrm{~B}$ & 11.34 & 98.65 \\
\hline \multirow{2}{*}{$2 \%(\mathrm{w} / \mathrm{w})$ suspensions $^{\mathrm{b}}$} & $1 \mathrm{~A}$ & 2.27 & 97.72 \\
\hline & $1 \mathrm{~B}$ & 2.26 & 97.73 \\
\hline \multirow{2}{*}{$1 \%(\mathrm{w} / \mathrm{w})$ suspensions $\mathrm{s}^{\mathrm{a}}$} & $1 \mathrm{~A}$ & 1.14 & 98.86 \\
\hline & $1 \mathrm{~B}$ & 1.13 & 98.87 \\
\hline
\end{tabular}

${ }^{\mathrm{a}}$ Used for turbidity measurements.

${ }^{\mathrm{b}}$ Used for swelling power measurements.

${ }^{\mathrm{c}}$ Used for rheological measurements.

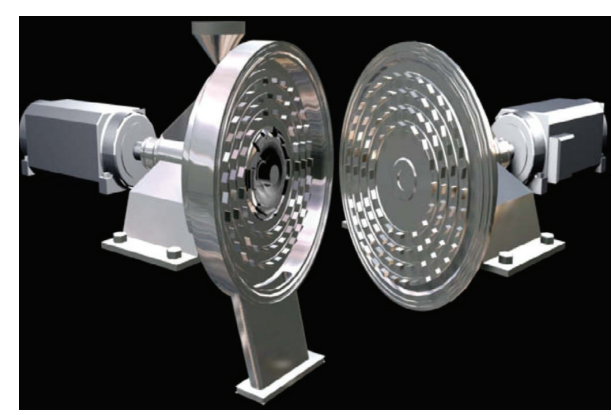

FIGURE 1: Laboratory equipment for tribomechanical micronization and activation (TMA equipment) [7].

atmospheric pressure. Overheating of the materials was prevented by water cooling of the equipment through its housing. Intake of the material for treatment was continuous at $1 \mathrm{~kg} / \mathrm{min}$ [7].

2.3. Particle Size Distribution. The particle size distribution of the powdered tapioca starch before and after TMA treatment was measured using a laser light scattering instrument, the Malvern Mastersizer 2000 (with a lens of $100 \mathrm{~mm}$ focal length). For analysis of the results obtained, MIE theory was applied [16]. Each analysis was made in triplicate, and the mean values were taken.

2.4. Scanning Electron Micrography of Tapioca Starch. For this investigation, scanning electron microscope Philips XL30 ESEM Tungsten, Philips, Eindhoven, The Netherlands (Edax detector, type PV 9760/68 ME, resolution $134.30 \mathrm{eV}$; BSE detector, Philips PW 6848/00), and software EDAX Genesis v. 5.21 were used for the characterization of air-dried, lyophilized, and spray-dried specimens. Photographs were taken at an accelerating voltage of $25.0 \mathrm{kV}$ under recording time of 5 seconds. Diameter of observed area was $10 \mathrm{~mm}$.

2.5. IR Spectroscopy. FTIR-Paragon 1000, Perkin Elmer, USA, Fouriers transformations,ART PIKE-s krystal (Instrument I-114/2-1/1), and software Spectrum, range of wavelength $550 \mathrm{~cm}^{-1}-24400 \mathrm{~cm}^{-1}$, with the resolution $4 \mathrm{~cm}^{-1}$. 
2.6. Solubility Index and Swelling Power Determination of Tapioca Starch Model Systems. The swelling power and solubility index of tapioca starch model systems before and after TMA treatment were determined in triplicate according to the method of Leach et al. [17]. Aqueous suspensions of $2 \%$ starch $(\mathrm{w} / \mathrm{w})$ were heated in a water bath at constant temperatures and shaked, for $30 \mathrm{~min}$. Each suspension was cooled and centrifuged at $3000 \mathrm{rpm}$ for $15 \mathrm{~min}$; the decanted was weighed, and the supernatant was placed in a vacuum stove at $120^{\circ} \mathrm{C}$ for $4 \mathrm{~h}$. Solubility index, SI (\%), has been calculated according to the equation:

$$
\begin{aligned}
& \mathrm{SI}=\left(W_{\mathrm{s}}-W_{0}\right) \times 100, \\
& W_{\mathrm{s}}-\text { percentage of the dry matter in supernatant }(\%) ; \\
& W_{0}-\text { percentage of the dry matter in the starting } \\
& \quad \text { suspension }(\%) .
\end{aligned}
$$

Swelling power, SP (g of hydrated molecules/g starch dry matter), is calculated according to

$$
\begin{aligned}
& \mathrm{SP}=\frac{W_{\mathrm{G}}}{W_{\mathrm{GDM}}}, \\
& W_{\mathrm{G}} \text { - gel mass }(\mathrm{g}) ; \\
& W_{\mathrm{GDM}} \text { - mass of gel dry matter }(\mathrm{g}) .
\end{aligned}
$$

2.7. Turbidity (Light Transmittance \%). Turbidity (light transmittance \%) of tapioca starch pastes was measured as described by Perera and Hoover [18]. An aqueous suspension of starch from each tapioca variety $(1 \mathrm{~g} / 100 \mathrm{~g}$ solids) was heated in a water bath at $90^{\circ} \mathrm{C}$ for $1 \mathrm{~h}$ with constant stirring. The starch pastes were cooled for $1 \mathrm{~h}$ at $30^{\circ} \mathrm{C}$, and the light transmittance was measured at $640 \mathrm{~nm}$. The samples were stored for 5 days at $4^{\circ} \mathrm{C}$ in a refrigerator, and transmittance was determined every $24 \mathrm{~h}$ with a Shimadzu UV-1601 spectrophotometer (Shimadzu Corporation, Kyoto, Japan).

\subsection{Determination of Rheological Properties of Tapioca Starch} Model Systems. Rheological properties of tapioca starch suspensions were determined according to the method of Hagenimana and Ding [19]. Tapioca starch suspension of $10 \%(\mathrm{w} / \mathrm{w})$ in $100 \mathrm{~mL}$ volume was directly placed into a stainless steel measuring bowl of a Brabender Micro-ViscoAmyloGraph (Duisburg, Germany). System operating at $250 \mathrm{rpm}$ was then heated from 30 to $93^{\circ} \mathrm{C}$, with a heating rate of $7.5^{\circ} \mathrm{C}$. Samples were held for $1 \mathrm{~min}$ at $52^{\circ} \mathrm{C}$ and $5 \mathrm{~min}$ at maximal temperature of $93^{\circ} \mathrm{C}$. The parameters recorded were maximum viscosity, breakdown viscosity, setback viscosity, and beginning of gelatinization $\left({ }^{\circ} \mathrm{C}\right)$.

2.9. Thermal Properties of Tapioca Starch. Gelatinization properties of tapioca starch suspensions were analyzed using a differential scanning calorimeter DSC 822e (Mettler Toledo) equipped with STARe software. An empty pan was used as a reference. Prepared and TMA-treated corn starch suspensions were weighed into a standard aluminum pan.
The pans were sealed and equilibrated for $24 \mathrm{~h}$ at room temperature before heat treatment in the DSC. The starch slurry was gelatinized in the DSC using a heat rate of $10^{\circ} \mathrm{C} / \mathrm{min}$ from 25 to $95^{\circ} \mathrm{C}$. After the heat treatment, the samples were cooled to $25^{\circ} \mathrm{C}$ and removed from DSC. The changes in enthalpy ( $\Delta H$ in $\mathrm{kJ} \mathrm{kg}^{-1}$ of dry starch), onset temperature $\left(T_{o}\right)$, peak temperature $\left(T_{P}\right)$, and conclusion temperature $\left(T_{c}\right)$ for gelatinization were obtained from the exothermal DSC curves. All the measurements were performed in triplicate.

2.10. Statistical Analyses. The whole study was repeated and each value represents the mean of three measurements from three independent tribomechanical treatments. The effect of tribomechanical treatment on tested parameters was determined by analysis of variance, using statistical analyses with SPSS for Windows version 13.0 (SPSS Inc., Chicago, IL). Analysis of variance (one-way ANOVA), significant level used was $5 \%(\alpha=0.05)$. The values not statistically different are accompanied by the letter (a) and the values statistically different by the letter (b).

\section{Results and Discussion}

3.1. Particle Size Distribution, Scanning Electron Micrography, and IR Spectroscopy of Tapioca Starch. The procedure of TMA treatment significantly changes the physical characteristics of the treated material [11]. Tribomechanical treatment causes micronization of various solid materials those results in nanoparticles and changes in structure and electrical potential of molecules [8]. Powdered tapioca starch during the TMA treatment is exposed to the strong mechanical forces of striking hammers and ventilation paddles placed on rotating discs which produce turbulent movement. In this way, tapioca starch particles collided and rubbed against each order in short time intervals (less than $0.001 \mathrm{~s}$ ). The strong mechanical forces which were producing turbulent cause collision between particles of tapioca starch and were rubbing against each order had caused rupturing and mechanical damages of starch granules and changes in their size and shape. TMA treatment significantly changes particle size distribution of tapioca starch. The changes of particle size distribution and specific surface area tapioca starch during the tribomechanical activation can be seen in Figure 2. Scanning electron micrography showed that tribomechanical processing of tapioca starch resulted in breaking accumulations of starch granules in the form of granules and surface defects granules (Figure 3). The content of amylose (\%) in starch is decrease after tribomechanical micronization $[20,21]$. A significant reduction in amylose content after tribomechanical micronization was observed. These results are in order with the results of the solubility index (\%) and swelling power (SP). Decrease in the content of amylose in granules of starch causes increase in swelling capacity and solubility of starch granules (Table 2). It is speculated that linear structure and random arrangement of amylose make amylose more susceptible to degradation [22].

IR spectroscopy showed that tribomechanical micronization and activation causes changes of tapioca starch granular 
TABLE 2: Values of solubility index (\%) and swelling power for native and modified tapioca starch suspensions after TMA treatment (1A (untreated) and 1B (TMA treated)).

\begin{tabular}{cccc}
\hline Sample & Determination conditions & Swelling power (g of hydrated molecules/g starch dry matter) & Solubility index (\%) \\
\hline & $20^{\circ} \mathrm{C} / 5 \mathrm{~min}$ & $2.89 \pm 0.12^{\mathrm{a}}$ & $0.22 \pm 0.05^{\mathrm{a}}$ \\
$1 \mathrm{~A}$ & $20^{\circ} \mathrm{C} / 15 \mathrm{~min}$ & $3.16 \pm 0.08^{\mathrm{a}}$ & $0.29 \pm 0.09^{\mathrm{a}}$ \\
& $70^{\circ} \mathrm{C} / 5 \mathrm{~min}$ & $4.17 \pm 0.07^{\mathrm{a}}$ & $0.43 \pm 0.11^{\mathrm{a}}$ \\
& $70^{\circ} \mathrm{C} / 15 \mathrm{~min}$ & $42.03 \pm 0.11^{\mathrm{a}}$ & $0.69 \pm 0.06^{\mathrm{a}}$ \\
\hline & $20^{\circ} \mathrm{C} / 5 \mathrm{~min}$ & $3.31 \pm 0.14^{\mathrm{a}}$ & $0.93 \pm 0.09^{\mathrm{b}}$ \\
$1 \mathrm{~B}$ & $20^{\circ} \mathrm{C} / 15 \mathrm{~min}$ & $3.42 \pm 0.04^{\mathrm{a}}$ & $1.27 \pm 0.01^{\mathrm{b}}$ \\
& $70^{\circ} \mathrm{C} / 5 \mathrm{~min}$ & $26.31 \pm 0.01^{\mathrm{b}}$ & $4.29 \pm 0.06^{\mathrm{b}}$ \\
& $70^{\circ} \mathrm{C} / 15 \mathrm{~min}$ & $52.16 \pm 0.02^{\mathrm{b}}$ & $6.95 \pm 0.08^{\mathrm{b}}$ \\
\hline
\end{tabular}

The values not statistically different are accompanied by the letter (a) and the values statistically different by the letter (b).

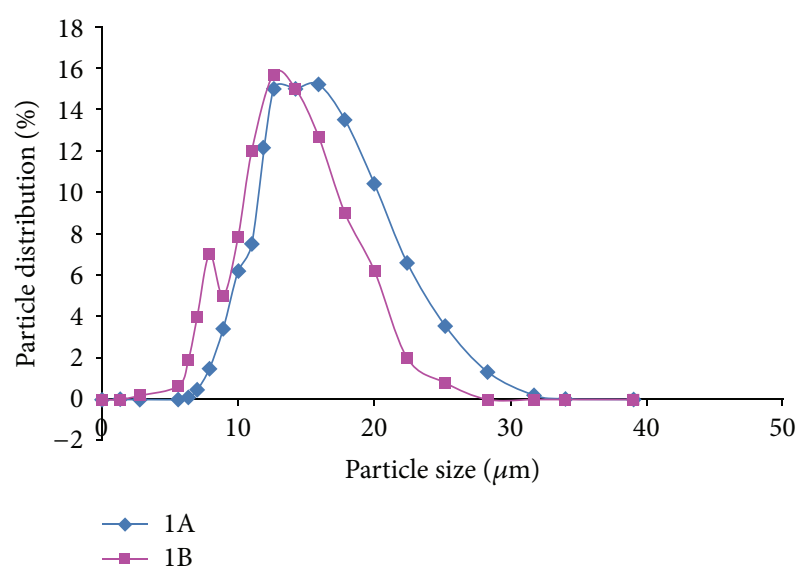

FIGURE 2: Granule size distribution of powered tapioca starch before and after tribomechanical treatment: $1 \mathrm{~A}$ - untreated tapioca starch; 1B-tribomechanically treated tapioca starch.

structure (Figure 4). The strong mechanical forces during the TMA treatment cause shear forces that are capable of breaking the chains of polymers and damaging granules [23]. After TMA treatment was expected splitting of long polymer chains of amylase and the separation of the carbohydrate molecules less of the molar mass (disaccharides, threesaccharides and so forth), FT-IR showed that in this case did not happen. Thus, there was no separation of a large number of short carbohydrate chains, and FT-IR did not detect them. It can be concluded that the changes that are visible on Figure 4, have consequence of tearing of long chains of amylase into smaller oligosaccharide chains wich are still extremely high molar masses. Huang et al. have explored the influence of mechanical activation on tapioca starch and have come up with similar results. In this study, infrared spectroscopy showed no new functional groups formed during the process of mechanical activation [24].

3.2. Physical Properties of Tapioca Starch Model Systems. The procedure of TMA treatment significantly changes the physical characteristics of the treated material [25]. Table 2 shows the changes in the swelling power and solubility of tapioca starch before and after TMA treatment. The solubility index and swelling power of the tapioca starch were analyzed in order to obtain information about the structural differences and molecular arrangement of the granules. The solubility index (SI) and swelling power (SP) of the starch gel prepared with suspension of TMA-treated tapioca starch had higher values when compared with untreated suspensions. It is caused by disruption of starch granules and molecule by TMA treatment. Swelling capacity and solubility index show us the size of the interaction of starch chains within the amorphous and crystalline areas of starch granules. Their interaction is determined by the ratio of amylose and amylopectin, phosphorus content, and their conformation and degree of branching [26]. The processing of starch leads to structural reorganization of the starch granules resulting in the rejection of the starch molecules, thereby facilitating the binding of water between the amorphous regions of granules and the consequent increase in the swelling capacity and solubility [27]. The increase in solubility comes as a result of the depolymerization and structural weakening of the starch granule [28]. Increases in solubility and swelling power when applying TMA treatment are also higher for samples at higher temperature $\left(70^{\circ} \mathrm{C}\right)$ than at $20^{\circ} \mathrm{C}$. Based on the results of measuring the absorbance at $640 \mathrm{~nm}$ on spectrophotometer for 5 days, significant differences after TMA treatment (Figure 5) in turbidity had been observed. Turbidity starch suspensions depend on the concentration of suspended particles in the volume of the measured absorbance. Perera and Hoover [18] explored the turbidity of native and modified starches and determined the existence of interaction between starch granules after completion of the modification. The demage on starch granules after mechanical modifications (tribomechanical) are mostly oriented to the surface of starch granules form conglomerates, which are rapidly precipitated from untreated starch granules themselves. The previous explanation is confirmed by the results of determining the turbidity of model starch suspensions tribomechanically treated tapioca starch, where after 5 days (up to 96 hours) of storage, a decrease in turbidity had been identified compared with the untreated samples (Figure 5). Singh et al. [26] also reported that the increase in turbidity affects the separation of amylose starch granules during swelling. 


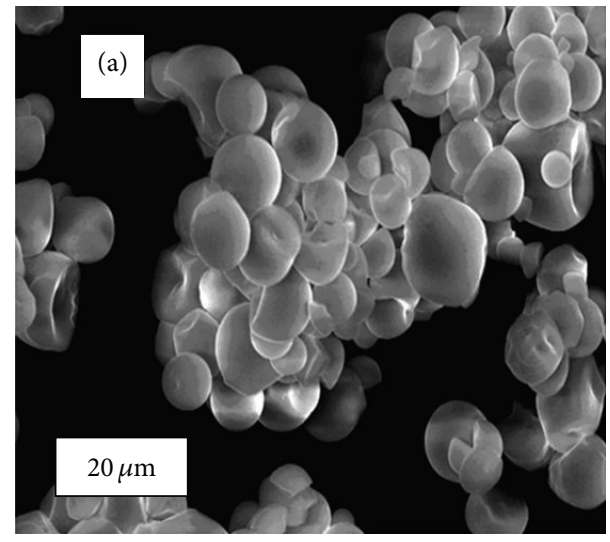

(a)

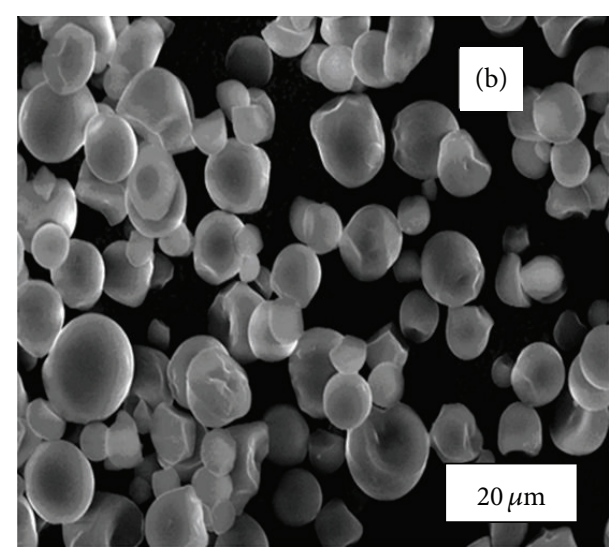

(b)

FIGURE 3: Scanning electron micrography of tapioca starch: (a) untreated; (b) TMA treated.

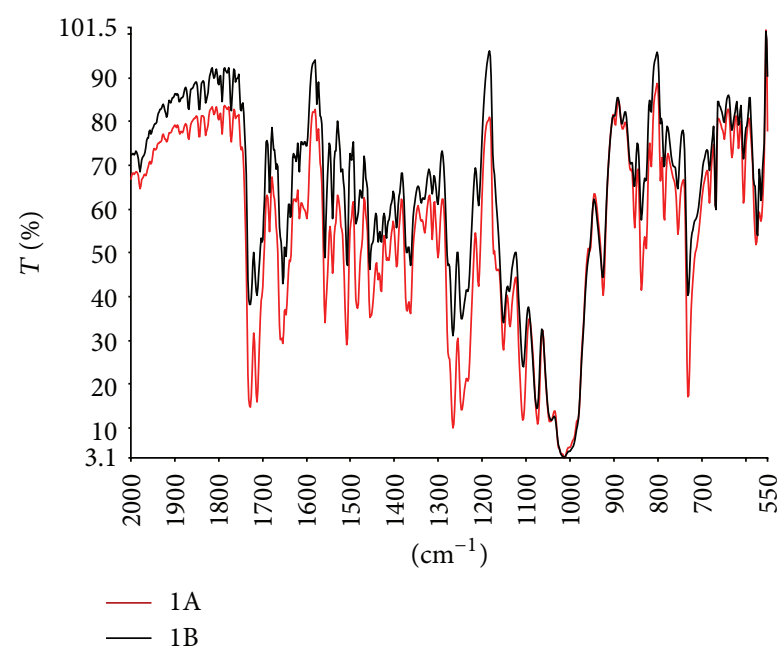

FIGURE 4: FTIR of tapioca starch: 1A — untreated tapioca starch; 1Btribomechanically treated tapioca starch.

3.3. Rheological and Thermophysical Properties of Tapioca Starch Model Systems. The recorded pasting properties of untreated and tribomechanically treated tapioca starch were pasting temperature, peak viscosity, trough viscosity (minimum viscosity at $95^{\circ} \mathrm{C}$ ), final viscosity (viscosity at $50^{\circ} \mathrm{C}$ ), breakdown viscosity (peak-trough viscosity), and setback viscosity (final-trough viscosity), as can be seen in Table 3 . The representative curves for untreated and TMA-treated tapioca corn starch are shown in Figure 6. TMA treatment has affected a decrease of starch suspension viscosity (Figure 6). Pasting parameters have shown that maximum viscosity of tapioca starch model suspensions (2474 BU) was decreasing after tribomechanical treatment (1990 BU). Breakdown viscosity (1475 BU) have also decreased (1105 BU) after TMA treatment but there is increase of setback viscosity (2091 BU) as compared with native tapioca starch (1904 BU). There is no change of gelatinization temperatures of tapioca starch after tribomechanical activation.

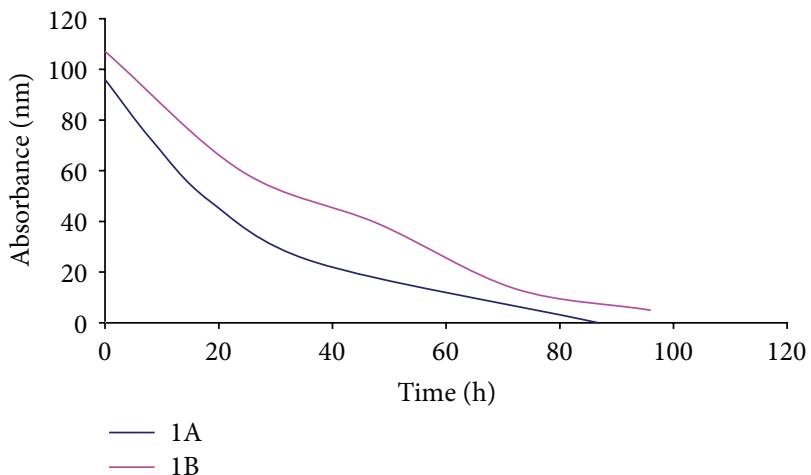

FIgURE 5: Turbidity of tapioca starch pastes before and after TMA treatment: $1 \mathrm{~A}$ - untreated; 1B-TMA treated.

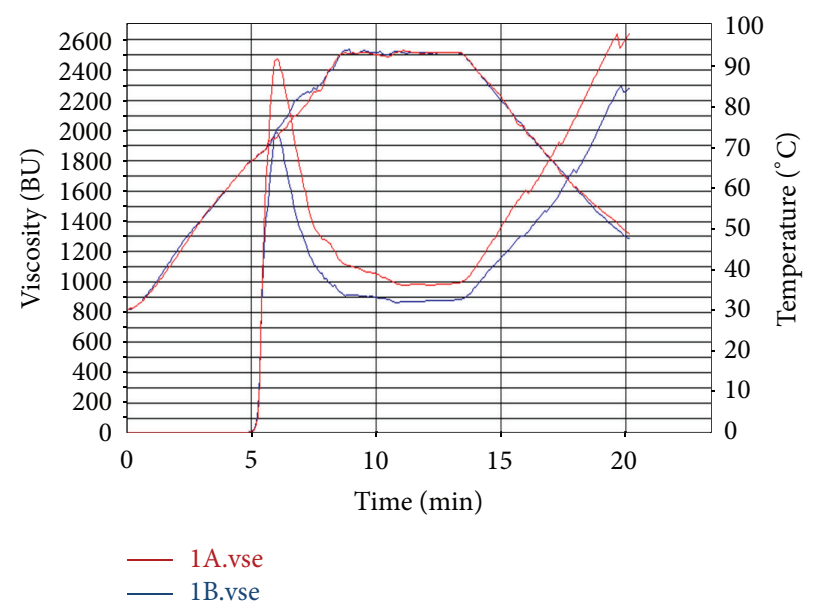

Figure 6: Viscosity of tapioca starch suspensions: 1A-untreated tapioca starch; 1B - tribomechanically treated tapioca starch.

The enthalpy of gelatinization $\left(\Delta H_{\text {gel }}\right)$, which represents the amount of thermal energy involved in the gelatinization process, was reduced after tribomechanical micronization of tapioca starch. TMA treatment brought about the weakening 
TABLE 3: Pasting properties of tapioca starch suspensions TMA treatment (1A (untreated) and 1B (TMA treated)).

\begin{tabular}{lcccc}
\hline Sample & Maximum viscosity $(\mathrm{BU})$ & Breakdown viscosity $(\mathrm{BU})$ & Setback viscosity $(\mathrm{BU})$ & Beginning of gelatinization $\left({ }^{\circ} \mathrm{C}\right)$ \\
\hline 1A & $2474 \pm 3.97^{\mathrm{a}}$ & $1475 \pm 5.77^{\mathrm{a}}$ & $1490 \pm 5.36^{\mathrm{a}}$ & $67.2 \pm 0.07^{\mathrm{a}}$ \\
1B & $1990 \pm 4.61^{\mathrm{b}}$ & $1105 \pm 3.79^{\mathrm{b}}$ & $2091 \pm 6.59^{\mathrm{b}}$ & $67.2 \pm 0.03^{\mathrm{a}}$ \\
\hline
\end{tabular}

The values not statistically different are accompanied by the letter (a) and the values statistically different by the letter (b).

TABLE 4: DSC parameters of native and modified tapioca starch suspensions after TMA treatment (1A (untreated) and 1B (TMA treated)).

\begin{tabular}{lcccccc}
\hline \multirow{2}{*}{ Sample } & Onset temperature & Peak temperature & Conclusion temperature & \multicolumn{2}{c}{$\Delta T\left({ }^{\circ} \mathrm{C}\right)$} & \multicolumn{2}{c}{ Entalpy of gelatinization } \\
& $T_{\mathrm{o}}\left({ }^{\circ} \mathrm{C}\right)$ & $T_{\mathrm{p}}\left({ }^{\circ} \mathrm{C}\right)$ & $T_{\mathrm{c}}\left({ }^{\circ} \mathrm{C}\right)$ & $T_{\mathrm{c}}-T_{\mathrm{o}}$ & $\Delta H(\mathrm{~kJ} / \mathrm{kg})$ \\
\hline $1 \mathrm{~A}$ & $65.93 \pm 0.03^{\mathrm{a}}$ & $70.48 \pm 0.01^{\mathrm{a}}$ & $81.55 \pm 0.02^{\mathrm{a}}$ & $15.62 \pm 0.03^{\mathrm{a}}$ & $50.626 \pm 0.05^{\mathrm{a}}$ \\
$1 \mathrm{~B}$ & $65.10 \pm 0.01^{\mathrm{a}}$ & $70.12 \pm 0.01^{\mathrm{a}}$ & $80.65 \pm 0.01^{\mathrm{a}}$ & $15.55 \pm 0.02^{\mathrm{a}}$ & $49.738 \pm 0.02^{\mathrm{a}}$ \\
\hline
\end{tabular}

The values not statistically different are accompanied by the letter (a), the values statistically different by the letter (b).

of starch granules, and, consequently, less energy was needed to gelatinize the starch granules. This explains the lower $\Delta H$ model suspensions of treated tapioca starch $\left(\Delta H_{\text {gel }}\right.$ $=49.738 \mathrm{~kJ} / \mathrm{kg}$ ) as compared with model suspensions of untreated tapioca starch $(50.626 \mathrm{~kJ} / \mathrm{kg})$. Model suspension of TMA-treated tapioca starch showed lower transition temperatures $\left(T_{o}, T_{P}\right.$, and $\left.T_{c}\right)$ as compared to untreated (Table 4). The decreases in the $T_{o}, T_{p}$, and $T_{c}$ of tapioca starches upon tribomechanical activation might be due to the weakening of the starch granules, which led to the early rupture of the amylopectin double helices [28]. TMA treatment of starch distorts the crystalline region in starch granules prior to a reversible hydration of the amorphous phase, which results in the destruction of the granular structure [11].

\section{Conclusion}

This study shows that tribomechanical micronization and activation, which presents a novel method for food processing, gives opportunity to modify and to improve rheological, thermophysical, and some physical properties of tapioca starch. Tribomechanical processing of tapioca starch resulted in breaking accumulations of starch granules in the form of granules. Pasting parameters have shown that maximal viscosities of model starch suspension were decreasing after tribomechanical treatment. Statistically significant increase in solubility and swelling power was observed. TMA treatment caused disrupting of starch granules by mechanical forces and made the granule more permeable to water during the heating step.

The enthalpy of gelatinization was reduced after tribomechanical micronization of tapioca starch. The decreases in the $T_{o}, T_{P}$, and $T_{c}$ of tapioca starches upon tribomechanical activation might be due to the weakening of the starch granules, which led to the early rupture of the amylopectin double helices and shear thinning of tapioca starch and increased its cold-water solubility. Such behavior is consistent with mechanical activation increasing the amorphous regions of the starch granules while weakening and decreasing the crystalline regions of the starch. Comparing TMA with other methods minimal food processing, tribomechanical activation has the advantages with its simple process, minimal environmental problems and convenient operation.

\section{References}

[1] A. Golachowski, "Application of starch and its preparationin food industry," Zeszyty Naukowe Akademii Rolniczej we Wrocławiu, vol. 328, pp. 117-124, 1998 (Polish).

[2] P. Tomasik, "Modified starches and their application," Polish Journal of Food and Nutrition Sciences, vol. 54, no. 4, pp. 16-18, 2000 (Polish).

[3] T. Funami, Y. Kataoka, T. Omoto, Y. Goto, I. Asai, and K. Nishinari, "Effects of non-ionic polysaccharides on the gelatinization and retrogradation behavior of wheat starch," Food Hydrocolloids, vol. 19, no. 1, pp. 1-13, 2005.

[4] L. M. Che, D. Li, L. J. Wang, X. D. Chen, and Z. H. Mao, "Micronization and hydrophobic modification of cassava starch," International Journal of Food Properties, vol. 10, no. 3, pp. 527-536, 2007.

[5] L. M. Che, D. Li, L. J. Wang, N. Özkan, X. D. Chen, and Z. H. Mao, "Effect of high-pressure homogenization on the structure of cassava starch," International Journal of Food Properties, vol. 10, no. 4, pp. 911-922, 2007.

[6] Y. Liang, B. S. Zhang, L. S. Yang, and D. W. Gao, "Chemicalreactionativity of tapioca starch with non-cristallized granule state," Journal of Zhengzhou Institute of Technology, vol. 25, pp. 9-13, 2004.

[7] T. Lelas, "Vorrichtung zum Micronisieren vom Materialien und neuartige Verwendungsmoglichkeiten derartig mikronisierter Materialien," Patent PCT/ 1B99/00757, Geneve, Switzerland, 1998.

[8] V. Lelas, "Novel food processing technologies," Dairy, vol. 56, pp. 311-330, 2006.

[9] Z. Herceg, V. Lelas, and M. Skreblin, "Influence of tribomechanical micronisation on the rheological properties of whey proteins," Food Technology and Biotechnology, vol. 40, no. 2, pp. 145-156, 2002.

[10] Z. Herceg, V. Lelas, and G. Krešić, "Influence of tribomechanical micronization on the physical and functional properties of whey proteins," International Journal of Dairy Technology, vol. 58, no. 4, pp. 225-232, 2005.

[11] Z. Herceg, V. Batur, A. R. Jambrak, M. Badanjak, S. R. Brnčić, and V. Lalas, "Modification of rheological, thermophysical, 
textural and some physical properties of corn starch by tribomechanical treatment," Carbohydrate Polymers, vol. 80, no. 4, pp. 1072-1077, 2010.

[12] F. E. Ortega-Ojeda and A. C. Elliason, "Gelatinisation and retrogradation behaviour of some starch mixtures," Starch, vol. 53, pp. 520-529, 2001.

[13] J. Babić, D. Šubarić, N. Nedić Tiban, and M. Kopjar, “The effect of lactose and whey powder on the gelatinization and retrogradation of tapioca starch," in Proceedings of the 4th International Symposium on Food Rheology and Structure (ISFRS '06), P. Fischer and E. J. Windhab, Eds., pp. 707-708, Zürich, Švicarska, 2006.

[14] J. Babić, D. Šubarić, Đ. Ačkar, V. Piližota, M. Kopjar, and N. Nedić Tiban, "Effect of pectin and carrageenan on thermophysical and rheological properties of tapioca starch," Czech Journal of Food Sciences, vol. 24, no. 6, pp. 275-282, 2006.

[15] D. Šubarić, J. Babić, Đ. Ačkar et al., "Effect of galactomannan hydrocolloids on gelatinization and retrogradation of tapioca and corn starch," Croatian Journal of Food Science and Technology, vol. 3, no. 1, pp. 26-31, 2011.

[16] C. F. Bohren and D. R. Huffman, Absorption and Scattering of Light By Small Particles, Wiley, New York, NY, USA, 1983.

[17] H. W. Leach, L. D. McCowen, and T. J. Schoch, "Structure of the starch granule. Swelling and solubility patterns of various starches," Cereal Chemistry, vol. 36, pp. 534-544, 1959.

[18] C. Perera and R. Hoover, "Influence of hydroxypropylation on retrogradation properties of native, defatted and heat-moisture treated potato starches," Food Chemistry, vol. 64, no. 3, pp. 361375, 1999.

[19] A. Hagenimana and X. Ding, "A comparative study on pasting and hydration properties of native rice starches and their mixtures," Cereal Chemistry, vol. 82, no. 1, pp. 70-76, 2005.

[20] B. Vidić, T. Vukušić, I. L. Herceg et al., "Influence od high intensity ultrasound on physical and textural properties of wheat starch," Croatian Journal of Food Technology, Biotechnology, vol. 4, pp. 134-140, 2011.

[21] Z. Herceg, S. Mededovic Thagard, V. Batur, and A. Režek Jambrak, "Effect of tribomechanical micronisation and activation treatment on textural and thermophysical properties of wheat and potato starch gels," Food technology and Biotechnology. In press.

[22] K. S. Sandhu, M. Kaur, N. Singh, and S. T. Lim, "A comparison of native and oxidized normal and waxy corn starches: physicochemical, thermal, morphological and pasting properties," Food Science and Technology, vol. 41, no. 6, pp. 1000-1010, 2008.

[23] V. V. Boldyrev, "Mechanochemistry and sonochemistry," Ultrasonics, vol. 2, no. 2, pp. S143-S145, 1995.

[24] Z. Q. Huang, J. P. Lu, X. H. Li, and Z. F. Tong, "Effect of mechanical activation on physico-chemical properties and structure of cassava starch," Carbohydrate Polymers, vol. 68, no. 1, pp. 128-135, 2007.

[25] G. Krešić, V. Lelas, A. Režek Jambrak, Z. Herceg, and S. Rimac Brnčić, "Influence of novel food processing technologies on the rheological and thermo-physical properties of whey proteins," Journal of Food Engineering, vol. 87, pp. 64-73, 2008.

[26] N. Singh, K. S. Sandhu, and M. Kaur, "Characterization of starches separated from Indian chickpea (Cicer arietinum L.) cultivars," Journal of Food Engineering, vol. 63, no. 4, pp. 441449, 2004.

[27] J. Singh, L. Kaur, and O. J. McCarthy, "Factors influencing the physico-chemical, morphological, thermal and rheological properties of some chemically modified starches for food applications-a review," Food Hydrocolloids, vol. 21, no. 1, pp. 122, 2007.

[28] J. E. Hodge and E. M. Osman, "Carbohydrates," in Food Chemistry, O. R. Fennema, Ed., Marcel Dekker, New York, NY, USA, 1996. 

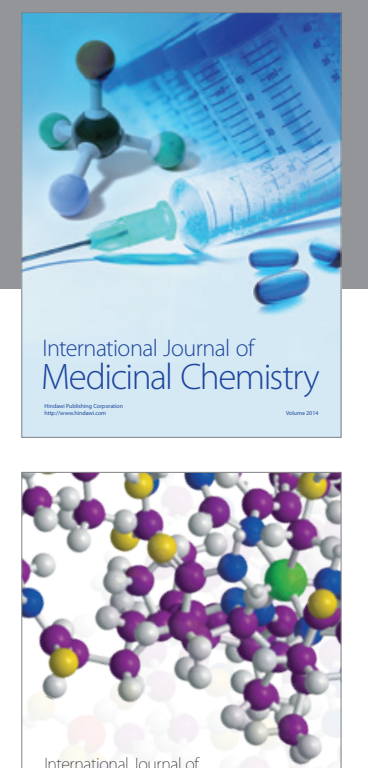

\section{Carbohydrate} Chemistry

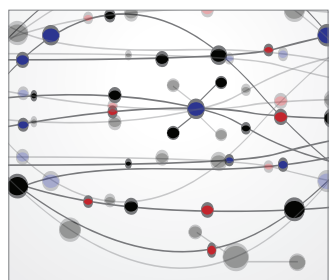

The Scientific World Journal
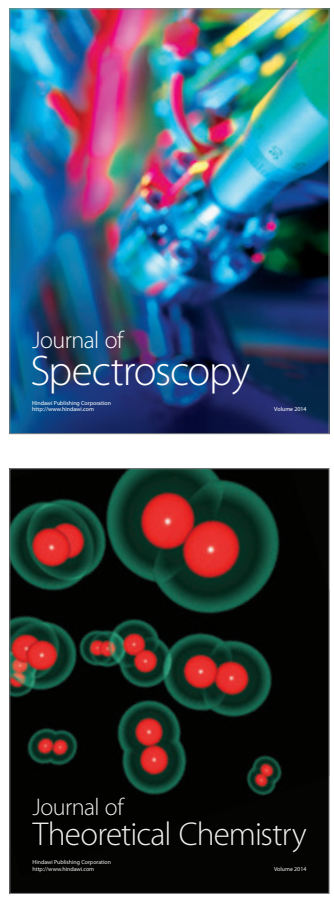
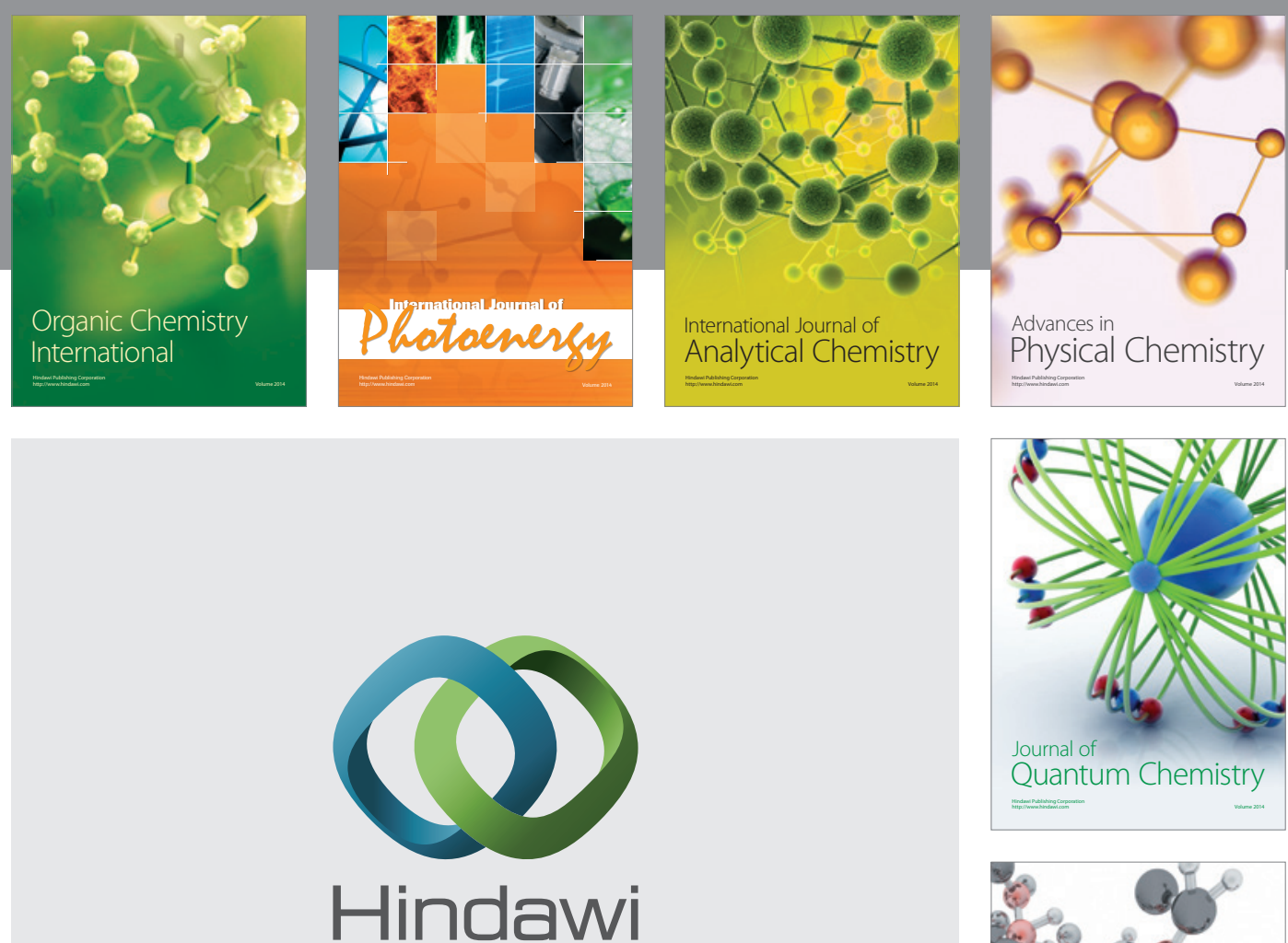

Submit your manuscripts at

http://www.hindawi.com

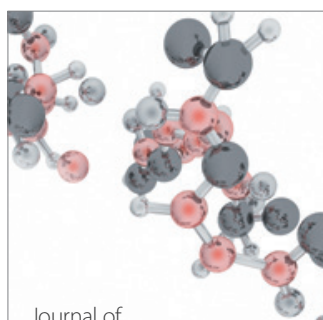

Analytical Methods

in Chemistry

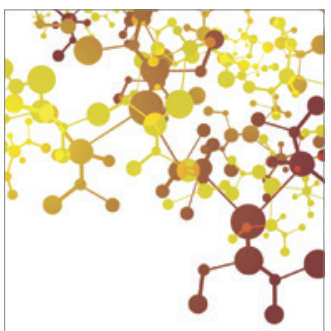

Journal of

Applied Chemistry

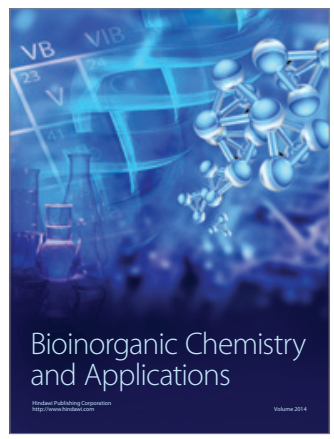

Inorganic Chemistry
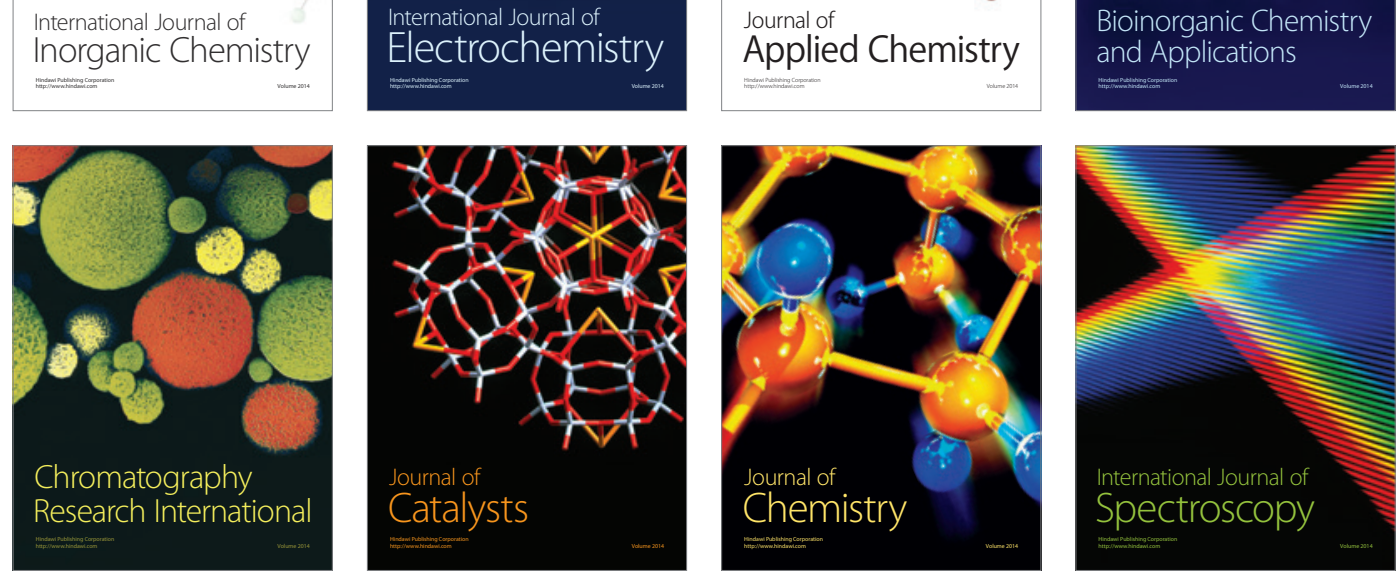